\title{
Wheat-barley hybridization: the last 40 years
}

\author{
Márta Molnár-Láng • Gabriella Linc • \\ Éva Szakács
}

Received: 10 July 2013/Accepted: 13 October 2013/Published online: 31 October 2013

(C) The Author(s) 2013. This article is published with open access at Springerlink.com

\begin{abstract}
Several useful alien gene transfers have been reported from related species into wheat (Triticum aestivum), but very few publications have dealt with the development of wheat/barley (Hordeum vulgare) introgression lines. An overview is given here of wheat $\times$ barley hybridization over the last forty years, including the development of wheat $\times$ barley hybrids, and of addition and translocation lines with various barley cultivars. A short summary is also given of the wheat $\times$ barley hybrids produced with other Hordeum species. The meiotic pairing behaviour of wheat $\times$ barley hybrids is presented, with special regard to the detection of wheatbarley homoeologous pairing using the molecular cytogenetic technique GISH. The effect of in vitro multiplication on the genome composition of intergeneric hybrids is discussed, and the production and characterization of the latest wheat/barley translocation lines are presented. An overview of the agronomical traits ( $\beta$-glucan content, earliness, salt tolerance, sprouting resistance, etc.) of the newly developed introgression lines is given. The exploitation and possible use of wheat/barley introgression lines for the most up-to-date molecular genetic studies
\end{abstract}

M. Molnár-Láng $(\bowtie) \cdot$ G. Linc · É. Szakács

Agricultural Institute, Centre for Agricultural Research,

Hungarian Academy of Sciences, Martonvásár,

Brunszvik 2 2462, Hungary

e-mail: molnar.marta@agrar.mta.hu (transcriptome analysis, sequencing of flow-sorted chromosomes) are also discussed.

Keywords Wheat $\times$ barley hybrids .

Additions · Translocations · Introgressions ·

Homoeologous pairing

\section{Introduction}

Wheat (Triticum aestivum L.) - alien hybridization makes it possible to transfer agronomically useful genes from one species to the other. Several useful alien gene transfers have been reported from wild species or rye (Secale cereale L.) into wheat, but very few publications have dealt with the development of wheat/barley (Hordeum vulgare L.) translocation lines. An overview is given here of wheat $\times$ barley hybridization over the last forty years, including the development and characterization of wheat/barley introgression lines in recent decades.

\section{Production of wheat $(T$. aestivum $) \times$ barley $(H$. vulgare $)$ hybrids, addition and substitution lines}

Crosses between wheat and barley, two of the most important cultivated cereals, could make it possible to incorporate the earliness, favourable amino acid composition, salt and drought tolerance and good 
tillering ability of barley into wheat. An even greater challenge would be the transfer of stem strength and winter hardiness from wheat into barley. Attempts to hybridize the two species began in the early 20th century, but the first demonstrably successful cross was reported by the Danish scientist Kruse in 1973. Encouraged by his success, attempts were made in several countries, aimed at producing new hybrids and progeny. Hybrids were developed at relatively greater frequency when barley was used as the female parent (Islam and Shepherd 1990). Barley $\times$ wheat hybrids were produced in numerous combinations by Islam et al. (1975), Fedak (1977), Thomas et al. (1977), Mujeeb-Kazi (1981), Clauss (1980), Shumny et al. (1981), Wojciechowska (1985) and Molnár-Láng et al. (1985). In crosses between a total of 18 barley varieties and 15 wheat varieties, the highest seed set was achieved when the wheat variety Chinese Spring (CS) was hybrized with the barley varieties Betzes and Ketch. A seed set of $15.4 \%$ was reported by Islam et al. (1975), while Fedak (1980) achieved $49 \%$ seed set, though only $2 \%$ of the latter developed into plants. The Chinese Spring-Hope substitution line series was used to determine the chromosomal location of genes in Chinese Spring that permit crossability with Betzes barley (Fedak and Jui 1982). No progeny were obtained from substitution lines 5A, 5B, 5D, indicating these chromosomes of Chinese Spring, homoeologous group 5, are the major chromosomes responsible for permitting crossability with Betzes barley. All the hybrid plants obtained were raised in embryo culture, since the hybrid seeds have no endosperm and the embryos would die if left in the florets (Islam and Shepherd 1990). The barley $\times$ wheat hybrids exhibited complete male sterility, but when backcrossed with wheat it proved possible to produce $\mathrm{BC}_{1}$ and $\mathrm{BC}_{2}$ plants. The seed set in the first backcross was extremely low (0.5-1.2 seeds/spike) (Islam and Shepherd 1990). Due to the pistilloidy observed in the $\mathrm{BC}_{1}$ and $\mathrm{BC}_{2}$ plants the progeny remained sterile despite several backcrosses, making it impossible to develop fertile addition lines.

In order to eliminate pistilloidy, attempts were made to make the reciprocal cross, where wheat was the female and barley the male parent, but far fewer laboratories were able to report successful crosses and these involved a much smaller number of combinations (Islam and Shepherd 1990; Fedak 1980; Wojciechowska and Pudelska 1993; Molnár-Láng and Sutka 1994; Molnár-Láng et al. 2000b; Jauhar 1995; Taketa et al. 1998). It was found by Islam et al. $(1978,1981)$ that in this case, too, crosses between CS wheat and Betzes barley gave the highest seed set, but this was only $1.3 \%$, compared with $15.4 \%$ for the reciprocal cross. In experiments carried out under optimum conditions in the Martonvásár phytotron, $3.3 \%$ seed set was achieved with this combination (Molnár-Láng and Sutka 1994). When the barley variety Martonvásári 50 was crossed with CS wheat, several hybrid plants were obtained when barley was the female partner, but in the reciprocal combination, despite a very low seed set $(0.18 \%)$, no hybrid plants could be obtained (Molnár-Láng and Sutka 1994). A relatively short time after the development of the first wheat $\times$ barley hybrids, addition lines $(2 \mathrm{H}, 3 \mathrm{H}, 4 \mathrm{H}$, $5 \mathrm{H}, 6 \mathrm{H}, 7 \mathrm{H})$ were also produced for the first time between CS wheat and the spring barley Betzes (Islam et al. 1978, 1981). By crossing this addition series with the relevant monosomic lines, substitution lines were developed by Islam and Shepherd (1992b, 1995) and Ya-Ping et al. (2003) for all the chromosomes except $1 \mathrm{H}$ and $5 \mathrm{H}$.

Despite many attempts, it proved extremely difficult to expand the number of genotypes that could be successfully crossed, and very few hybrids were developed from genotypes with satisfactory agronomic traits (Wojciechowska and Pudelska 1993; Jauhar 1995; Taketa et al. 1998). It proved impossible to develop $\mathrm{BC}_{1}$ seed on a substantial proportion of the new hybrids, so no fertile progeny could be obtained from the new combinations (Wojciechowska and Pudelska 1993; Jauhar 1995). The efficiency of hybrid development was greatly improved by Koba et al. (1991), who used the 2,4-D treatment that had been successfully applied in wheat $\times$ maize crosses. A number of Japanese wheat varieties were included in the crosses, among which Norin 12, Norin 61 and Shinchunaga gave better seed set than CS when pollinated with the barley variety Betzes. The highest seed set $(8.25 \%)$ was obtained from the Norin $12 \times$ Betzes combination. $\mathrm{F}_{1}$ hybrids could be produced from most of the embryos through embryo culture (Koba et al. 1991). Addition lines containing the barley chromosomes $5 \mathrm{H}$ and $6 \mathrm{H}$ were developed from a cross between the wheat variety Shinchunaga and the barley variety Nyugoruden, and translocation lines were produced containing the 5HS.5BL translocation chromosome pair in addition to 42 wheat 
chromosomes (Koba et al. 1997). Backcross progenies $\left(\mathrm{BC}_{1}\right.$ and $\left.\mathrm{BC}_{2}\right)$ were developed from the combination of wheat cv. Shinchunaga $\times$ barley line T3-7aai by Malysheva et al. (2003) in Germany. The genome composition of the backcross progenies was analysed using genomic in situ hybridization (GISH) and microsatellite markers. Some of the barley chromosomes $(2 \mathrm{H}, 4 \mathrm{H})$ were entirely eliminated from the $\mathrm{BC}_{2}$ plants, the presence of $1 \mathrm{H}$ caused sterility, and chromosome segments from other barley chromosomes $(3 \mathrm{H}, 5 \mathrm{H}, 6 \mathrm{H}, 7 \mathrm{H})$ were detected in some $\mathrm{BC}_{2}$ plants. The development of disomic addition lines from this combination was not reported.

Barley has great genetic diversity for many agronomically important traits (spring or winter habit, tworowed or six-rowed, tolerance to abiotic stresses, yield ability, earliness, quality, adaptation, etc.). In order to utilise the useful agronomic traits of barley cultivars it would be worth producing wheat/barley addition and introgression lines with agronomically adaptable winter barley cultivars. A series of two new additions was reported from the wheat $\times$ barley hybrids produced with winter barley cultivars in Martonvásár (Molnár-Láng et al. 2000b). Backcross progenies were developed on the hybrids at very low frequency (Molnár-Láng et al. 2000b, 2005). Wheat-barley disomic addition lines $(2 \mathrm{H}, 3 \mathrm{H}, 4 \mathrm{H}, 6 \mathrm{HS}, 7 \mathrm{H}, 1 \mathrm{HS}$ isochromosome) were produced and identified using molecular cytogenetic methods from hybrids between winter wheat line Mv9kr1 and the German two-rowed winter barley Igri (Szakács and Molnár-Láng 2007, 2010). In order to increase the allelic variation in wheat/barley introgressions, new wheat/barley disomic addition lines were developed containing the $2 \mathrm{H}$, $3 \mathrm{H}, 4 \mathrm{H}, 6 \mathrm{H}$ and $7 \mathrm{H}$ chromosomes of the six-rowed Ukrainian winter barley cultivar Manas (Molnár-Láng et al. 2012). This cultivar is agronomically much better adapted to Central European environmental conditions than the two-rowed spring barley cultivar Betzes previously used.

\section{Wheat $\times$ barley hybrids produced with other Hordeum species}

In addition to cultivated hexaploid wheat (T. aestivum L.) and cultivated barley (Hordeum vulgare L.), hybrids have also been developed between other Triticum and Hordeum species, the most successful of which is hexaploid tritordeum, which arose from a cross between Triticum turgidum L. ssp. durum (Desf.) Husn. (synonym: T. durum) and Hordeum chilense Roem. et Schulz. (Martín and Sanchez-Monge Laguna 1980, 1982). H. chilense was previously pollinated with hexaploid $T$. aestivum to produce an $\mathrm{F}_{1}$ hybrid (Martín and Chapman 1977), from which a partially fertile amphidiploid was produced by means of colchicine treatment (Chapman and Miller 1978). The amphidiploid was then backcrossed to wheat to develop wheat/H. chilense addition lines (Miller et al. 1981). Later, H. chilense was pollinated with Triticum durum, after which the hybrid was treated with colchicine to develop fertile amphidiploids with 42 chromosomes (Martín and Sanchez-Monge Laguna 1980, 1982). As this new amphidiploid exhibited fewer meiotic chromosome pairing anomalies and fertility problems than the primary triticale, it was assumed that, like triticale, it could be cultivated as a new plant species, and was named tritordeum. Hexaploid tritordeum was found to have a protein content of 19-24 \% (Martín and Cubero 1981), so numerous analyses were made to provide a detailed description of the quality parameters of the new species. After 6-7 years of self-fertilisation in field experiments, it was established that the new species yielded only $20-40 \%$ as much as cultivated wheat, but had a protein content amounting to 17.6-25.2\% of the dry matter (Cubero et al. 1986). Its other quality parameters (fibre, lignin, cellulose and hemicellulose contents, amino acid composition) were similar to those of cultivated wheat. A multi-location study under varying growth conditions revealed important information about the effect of water availability on the yield of tritordeum. In the lowest yielding environments tritordeum and triticale had similar yields (Villegas et al. 2010). However, under better growth conditions tritordeum was found to yield less than wheat and triticale. It is suggested that tritordeum could be a new option for cultivation in very dry environments.

In the course of cytological analyses, the chromosome number and chromosome pairing of the new species were first monitored using the Feulgen method, which revealed a high level of chromosome stability (Martín and Cubero 1981). Later the $H$. chilense chromosomes were studied by means of C-banding (Fernandez et al. 1985) and fluorescence in situ hybridization (FISH) using repetitive DNA sequences (Cabrera et al. 1995). Hybridization with 
the pAs1 DNA clone isolated from Aegilops squarrosa (synonym: Ae. tauschii Coss.) gave a hybridization pattern similar to that of the $\mathrm{D}$ genome chromosomes of wheat for the H. chilense chromosomes, with strong hybridization signals on the telomeres. The chromosomes of Hordeum vulgare cannot be identified with this probe, as it gives diffuse signals on barley. The hybridization pattern obtained with $\mathrm{C}$-banding bore more resemblance to that of the wheat chromosomes and strong telomeric bands were observed on the $H$. chilense chromosomes, while in the case of $H$. vulgare chromosomes, C-banding revealed interstitial bands near the centromere (Cabrera et al. 1995). Molecular cytogenetic analysis showed that $H$. chilense was genetically distant from cultivated barley. Numerous papers have been published on the taxonomical classification of Hordeum species (Löve 1982, 1984; Dewey 1984), which were first classified on the basis of morphological observations, then on the basis of chromosome pairing in interspecific hybrids, and later in terms of the conclusions drawn from molecular genetic analysis. Bothmer et al. $(1986,1987)$ used the data of chromosome pairing analysis to divide the Hordeum species into four basic genomes (I, Y, X and $\mathrm{H})$. Molecular genetic analysis later confirmed this classification (Svitashev et al. 1994), showing that $H$. vulgare and $H$. bulbosum contained genome I and $H$. murinum genome $\mathrm{Y}$, while $H$. chilense was one of the species carrying the $\mathrm{H}$ genome, and $H$. marinum Huds. had an X genome. This classification confirmed the relatively distant relationship between $H$. vulgare and H. chilense.

In an effort to improve the agronomic traits of tritordeum, further crosses were made, primarily with triticale. The progeny were then analysed using various cytogenetic methods (Fernandez-Escobar and Martín 1985; Lima-Brito et al. 1996). The chromosomes of both $H$. chilense and rye could be identified by means of FISH (Lima-Brito et al. 1996). The hexaploid tritordeum was also crossed with $H$. vulgare, but the amphidiploid developed by treating the $F_{1}$ hybrid with colchicine proved to be sterile (Martín et al. 1995). Transgenic lines were developed by transforming tritordeum (Barcelo et al. 1994) and these were later studied in nursery experiments (Hernandez et al. 2001). A new cytoplasmic male sterility (CMS) source designated msH1 has been reported in bread wheat by Martín et al. (2009). This system uses the cytoplasm of $H$. chilense. The male sterility of alloplasmic wheat containing $H$. chilense cytoplasm is stable under various environmental conditions and the plants exhibit no developmental or floral abnormalities, except for slightly reduced height and some delay in heading. There is thus real potential for the development of a viable technology for hybrid wheat production. The addition of chromosome $6 \mathrm{H}^{\text {ch }} \mathrm{S}$ from $H$. chilense accession $\mathrm{H} 1$ was able to restore the pollen fertility of the CMS phenotype induced by the presence of $H$. chilense cytoplasm in wheat. An optimal combination for fertility restoration was the translocation $\mathrm{T} 6 \mathrm{H}^{\mathrm{ch}} .6 \mathrm{DL}$, developed by Martín et al. (2009).

In addition to Hordeum chilense, the following Hordeum species have been hybridised with wheat:

- H. spontaneum [syn.: H. vulgare ssp. spontaneum (C. Koch) Thell] (Islam and Shepherd 1990; Taketa et al. 1995),

- H. bulbosum L. (Barclay 1975; Blanco et al. 1986),

- H. bogdanii Wil. (Kimber and Sallee 1976),

- H. pussillum Nutt. (Finch and Bennett 1980),

- H. geniculatum All. (Clauss 1983; Pershina et al. 1988),

- H. pubiflorum Hook. f. (Fedak 1983),

- H. californicum Covas \& Stebbins [syn.: H. brachyantherum Nevski ssp. californicum (Covas \& Stebbins)] (Gupta and Fedak 1985),

- H. marinum Huds. (Jiang and Dajun 1987; Islam et al. 2007; Pershina et al. 2009),

- H. depressum (Scribn. \& Smith) Rydb. (Jiang and Dajun 1987).

A complete set of wheat-wild barley (Hordeum vulgare ssp. spontaneum) chromosome addition lines was developed by Taketa and Takeda (2001). The chromosome constitution of the addition lines was confirmed by C-banding and GISH hybridization. Addition lines for the entire $1 \mathrm{H}$ chromosome and its long arm are only available as monosomic and monotelosomic additions, respectively, because of sterility. Disomic additions involving individual chromosomes of sea barleygrass (Hordeum marinum Huds.) in CS wheat were obtained by Islam and Colmer (2008). The salt tolerance of the wheat $-H$. marinum amphiploid was intermediate to that of its parents (Islam et al. 2007). Alloplasmic wheat-barley substitution and addition lines were produced by Pershina et al. (2009) from H. marinum ssp. gussoneanum Huds. $\times$ T. aestivum hybrids. 


\section{In vitro multiplication of wheat $\times$ barley hybrids}

Sterile interspecific and intergeneric hybrids can be maintained and multiplied in a vegetative manner through callus formation in tissue culture (in vitro). Interspecific and intergeneric hybrids produced in wide crosses are often not only male sterile, but also have such a low level of female fertility that seeds are only set at extremely low frequency even when pollinated with one of the parents. Tissue culture makes it possible to multiply hybrids that can only be developed at very low frequency, thus producing enough progeny for backcrossing. The in vitro multiplication of interspecific and intergeneric hybrids developed between cereal species has been reported for various combinations: barley $\times$ rye (Shumny and Pershina 1979); wheat $\times$ rye (Armstrong et al. 1983; Doré et al. 1988); Aegilops crassa (Triticum crassum) $\times$ Hordeum vulgare (Nakamura et al. 1981); wheat $\times$ Agropyron hybrids (Sharma et al. 1984; Bai and Knott 1993); Elymus canadensis L. $\times$ Psathyrostachys juncea (Fisch.) Nevski (Park et al. 1990). When the progeny were subjected to cytological analysis, deviations were observed in all cases compared with the initial hybrids. It was established that the somaclonal variability observed during the in vitro multiplication of plants (Larkin and Scowcroft 1981) could lead to useful rearrangements during the maintenance of interspecific and intergeneric hybrids in tissue culture (Fedak 1985). Amphidiploids with a doubled chromosome number have been successfully produced from $\mathrm{F}_{1}$ hybrids (Doré et al. 1988; Ter Kuile et al. 1988), translocations have been observed (Sharma et al. 1984) and in some cases the regenerants have been found to have increased fertility (Sharma et al. 1984; Fedak and Grainger 1986; Molnár-Láng et al. 1991).

Wheat-barley hybrids were multiplied in tissue culture by Pershina and Shumny (1981), Chu et al. (1984), Junming et al. (1985), Galiba et al. (1986), Surikov and Kissel (1988) and Koba et al. (1988). Detailed cytological analyses on the regenerants were published by Junming et al. (1985), Fedak and Grainger (1986), Shimada et al. (1987) Fedak et al. (1987) and Molnár-Láng et al. (1991). Chromosome numbers differing from that of the initial hybrid (28) were observed by Junming et al. (1985) and Koba et al. (1988) in some regenerants (21-27) and all the authors recorded the occurrence of amphidiploid cells. The appearance of telocentric chromosomes in the regenerants was observed in several experiments (Junming et al. 1985; Koba et al. 1988; Molnár-Láng et al. 1991). A detailed analysis was made of the meiosis of regenerant hybrids by Molnár-Láng et al. (1991), who found an increase in the rate of homoeologous chromosome pairing. A similar conclusion was drawn by Dahleen (1999) when investigating the progeny regenerated from barley $\times$ wild rye hybrids in tissue culture. As no backcross seeds were obtained from the initial hybrid of facultative wheat cv. Asakaze $\times$ winter barley cv. Manas, young inflorescences of the hybrids were used for in vitro multiplication in three consecutive cycles until a backcross progeny was developed. The chromosome constitution of the regenerated hybrids was analysed using GISH after each in vitro multiplication cycle (Molnár-Láng et al. 2005). The seven barley chromosomes were present even after the third cycle but abnormalities were observed. Chromosome breakages occurred; the number of barley telocentrics became significantly higher after the third cycle and amphidiploid cells with 56 chromosomes were counted. The number of wheatbarley chromosome arm associations, i.e. homoeologous pairing frequency increased after in vitro multiplication (Molnár-Láng et al. 2005).

\section{Chromosome pairing in wheat $\times$ barley hybrids}

The meiotic pairing behaviour of wheat $\times$ barley hybrids was first analysed with the Feulgen method by several scientists. Islam and Shepherd (1980) observed 28 univalent chromosomes in the meiosis of wheat $\times$ barley hybrids in the majority of the cells, though in a few cells chromosome pairing could be seen, with an average of 0.7 bivalents per pollen mother cell. A higher rate of chromosome pairing was recorded by Fedak (1977) in the meiosis of barley $\times$ wheat hybrids, resulting in a chiasma frequency of 1.82 per pollen mother cell. This was higher than the rate reported earlier in wheat haploids (Riley and Law 1965), suggesting that pairing also took place between barley and wheat chromosomes. Fedak (1977) drew attention to the phenomenon of homoeologous pairing between the chromosomes of two distantly related genera, and suggested that this should be confirmed with the Giemsa technique, the best method available at the time. Later Jauhar (1995) demonstrated a 
chiasma frequency of 2.16-6.72 per pollen mother cell in wheat $\times$ barley hybrids developed using the barley variety Luther. These data pointed to pairing between wheat and barley chromosomes, but as the chromosomes were analysed in meiosis using the Feulgen method, it was not possible to identify the individual chromosomes. An average of 5.03-6.63 bivalents per pollen mother cell could be observed in wheat $\times$ barley hybrids produced using the $P h$ mutant of CS, together with a small number of trivalents and quadrivalents (Sethi et al. 1986), but pairing between wheat and barley could not be demonstrated with the Feulgen method. Wojciechowska (1985) performed detailed meiosis analysis in several barley $x$ wheat hybrid combinations and found a chiasma frequency of 1.17-1.98 per pollen mother cell in hybrid cells containing 28 chromosomes.

Islam and Shepherd (1988) elaborated a method for the detection of pairing between wheat and barley chromosomes. They crossed ditelosomic wheat/barley addition lines with a high-pairing strain of an Ae. speltoides genotype carrying the $P h$ suppressor gene. $\mathrm{F}_{1}$ hybrids possessing $28+1$ telocentric somatic chromosomes (21 wheat +7 Ae. speltoides plus 1 barley telocentric) were grown. Pairing between telocentric and non-telocentric chromosomes was observed in $1.2-4.5 \%$ of the pollen mother cells. Triple monosomic addition lines were developed in a wheat monosomic background, one of which contained 19 pairs of wheat chromosomes together with one 5B Ph mutant chromosome, one $3 \mathrm{HL}$ barley chromosome arm and a 3A wheat chromosome (Islam and Shepherd 1992a). In another line the 5B Ph mutant was accompanied by one $6 \mathrm{HS}$ and one $6 \mathrm{~B}$ chromosome. In the triple monosomic addition lines, plants carrying the $3 \mathrm{HL}$ and $6 \mathrm{HS}$ barley chromosome arms only exhibited pairing in $0.3-0.7 \%$ of the cells. These experiments proved that chromosomes of the distantly related species wheat and barley are capable of pairing with each other, thus allowing recombinations to occur.

The meiotic instability of wheat $\times$ barley hybrids was noted by a number of authors, who found many cells with hypo- or hyperploid chromosome numbers in addition to cells with 28 chromosomes (Fedak 1980; Mujeeb-Kazi and Rodriguez 1983; Islam and Shepherd 1980; Wojciechowska 1985). Islam and Shepherd (1980) observed that the chromosome number became doubled in some cells during meiosis (restitution nuclei). In these hybrids the univalent chromosomes assembled in the equatorial plate during metaphase I of meiosis, but in many cells, instead of migrating to the two poles in anaphase I, the chromosomes remained together, forming a chromatin mass, thus leading to the formation of cells with a doubled chromosome number. In these cells, however, it was often observed that the second phase of meiosis did not take place, preventing the development of microspores with the full chromosome complement, which would restore the fertility of the hybrids (Islam and Shepherd 1980). It can be assumed that the egg-cells which became fertilised and set seed when the hybrids were backcrossed arose from megaspores with a doubled chromosome number.

Wheat-barley chromosome pairing was first detected using GISH by Molnár-Láng et al. (2000b). Meiotic analysis of the wheat $\times$ barley hybrid Mv9 kr1 $\times$ Igri revealed 1.59 chromosome arm associations per cell using the Feulgen method (Molnár-Láng et al. 2000b). The number of chromosome arm associations increased to 4.72 after in vitro culture. According to GISH analysis, wheat-barley chromosome arm associations made up $3.6 \%$ of the total in the initial hybrid and $16.5 \%$ of the total in progenies of the Mv9 kr1 $\times$ Igri hybrids regenerated in vitro. The meiotic pairing behaviour of a wheat-winter barley hybrid (Asakaze $\times$ Manas) was analysed using GISH after long-term maintenance in tissue culture (MolnárLáng et al. 2005) (Fig. 1). As no backcross seeds were obtained from the initial hybrid, young inflorescences of the hybrids were used for in vitro multiplication in three consecutive cycles until a backcross progeny was developed. The chromosome constitution of the regenerated hybrids was analysed using GISH after each in vitro multiplication cycle. The number of wheatbarley chromosome arm associations increased after the second and third cycles. Amphidiploid cells containing seven barley bivalents were counted after the third cycle. The use of the GISH technique to demonstrate wheat-barley chromosome pairing in the hybrids, and especially in their in vitro-regenerated progenies, proved the possibility of producing recombinants between these two genera, and thus of transferring useful characters from barley into wheat (Molnár-Láng et al. 2000b, 2005). In some regenerants in vitro conditions caused an increase in chromosome arm association frequency and in fertility. 


\section{Production of wheat/barley recombination and translocation lines}

Islam and Shepherd (1992a) were the first to develop recombinations from wheat $\times$ barley crosses. Triple monosomics were developed from crosses between wheat/barley ditelosomic substitution lines and the $P h$ mutant of CS wheat. In addition to 19 wheat chromosome pairs, the triple monosomic additions contained one barley telocentric chromosome, the homoeologous wheat chromosome and one 5B Ph mutant chromosome. With this method wheat/barley recombinations involving six $6 \mathrm{HL}$ and six $3 \mathrm{HL}$ chromosome segments were detected among the progeny. The presence of the recombinations was proved by isoenzyme analysis: the progeny were found to contain isoenzymes located either on the $6 \mathrm{~A}$ and $6 \mathrm{H}$ or on the $3 \mathrm{~A}$ and $3 \mathrm{H}$ chromosomes. Sherman et al. (2001) also utilised the effect of the $P h$ mutant gene to develop recombinations from the $4 \mathrm{H}$ and $5 \mathrm{H}$ wheat/barley addition lines produced by Islam et al. (1981). The presence of the recombinations was confirmed with PCR-based molecular markers. The use of GISH to detect the occurrence of wheat-barley translocations was first reported by Schwarzacher et al. (1992). The translocation line was developed by Islam and Shepherd (unpublished data) and isoenzyme analysis proved that at least the segment of the 4HL barley chromosome arm carrying the gene coding for the barley $\beta$-amylase isoenzyme had been incorporated into this line. GISH analysis then demonstrated that the whole of the 4HL chromosome arm was present in the translocation line, i.e. a centric fusion had occurred between wheat and barley. The occurrence of spontaneous translocations was observed by Koba et al. (1997) in the progeny of a cross between Shinchunaga wheat and Nyugoruden barley. The translocation chromosome was identified with C-banding and, using an earlier nomenclature, it was found that it involved the short arm of chromosome 7 of barley and the long arm of wheat chromosome 5B. When the names of the barley chromosomes were later revised, the old chromosome 7 was renamed 5H (Linde-Laursen et al. 1997) and it became clear that a homoeologous translocation had indeed taken place.

Various methods are available for producing translocations, including irradiation (Sears 1956, Szakács et al. 2010) or the induction of homoeologous pairing (Riley and Chapman 1958; Sears 1972; Griffiths et al.
2006). A number of genes from common wheat promote chromosome pairing and several act as inhibitors (Sears 1976). The pairing homoeologous gene, $P h l$, on the long arm of chromosome 5B, has the most decisive effect. In its presence, pairing is restricted to homologues; in its absence, homoeologues also pair, albeit less frequently than homologues. The simple deletion of $P h 1$, or the counteraction of its effect by high-pairing types of Ae. speltoides or Ae. mutica, can induce many Triticinae chromosomes to pair with their wheat homoeologues. Such induced homoeologous pairing is usually the method of choice for transferring genes from alien chromosomes to those of wheat. The "Ph system" was used by Islam and Shepherd (1992a) and by Sherman et al. (2001) to produce wheat-barley translocations. A unique genetic system exists in common wheat, which induces frequent chromosomal structural rearrangements. This system, the gametocidal (Gc) system, involves alien chromosomes called Gc chromosomes, which were introduced into common wheat from certain wild species belonging to the genus Aegilops. This system proved to be effective in inducing structural rearrangements in the barley chromosomes added to common wheat, as well as in common wheat chromosomes (Endo 2009). The rearranged chromosomes thus induced include deletions of barley chromosomes and translocations between the barley and wheat chromosomes. Lines carrying rearranged barley chromosomes are designated as 'dissection lines' (Endo 2009). Schubert et al. (1998) developed wheat-barley translocations from wheat/ barley disomic addition lines by exploiting the gametocidal effect of the 2C chromosome of Aegilops cylindrica. The $7 \mathrm{H}$ wheat/barley addition line was crossed with the $2 \mathrm{C}$ wheat/Ae. cylindrica addition line and the resulting line, containing two different alien chromosomes, was self-fertilised. Lines carrying barley deletions and wheat-barley translocations were selected from the progeny. More than ten translocation lines carrying segments of the $7 \mathrm{H}$ barley chromosome were produced. The incorporation of the barley chromosome segments was detected by means of GISH, and with FISH using the repetitive probe HvT01. These 7H deletion and translocation lines were then used for the physical mapping of the $7 \mathrm{H}$ barley chromosome (Serizawa et al. 2001). Nasuda et al. (2005), Ashida et al. (2007) and Sakai et al. (2009) performed deletion mapping on barley chromosomes $7 \mathrm{H}, 5 \mathrm{H}$ and $3 \mathrm{H}$ using barley dissection lines and barley-specific EST 
markers. The barley dissection lines were produced from CS-Betzes addition lines, so they all carried chromosome segments from Betzes barley.

Molnár-Láng et al. (2000a) developed translocations from wheat-barley hybrids regenerated in tissue culture, using GISH for confirmation. The origin of the barley chromosome segments involved in the selected homozygous translocation lines was determined using molecular markers (Nagy et al. 2002). Segments of various sizes from the $1 \mathrm{H}, 3 \mathrm{H}, 4 \mathrm{H}$ and $5 \mathrm{H}$ chromosomes were found to have been incorporated in the translocation lines. These lines were then used for the physical mapping of microsatellite markers previously located on the barley chromosomes. Sepsi et al. (2006) produced wheat/barley translocations as the result of induced homoeologous chromosome pairing in a 4H(4D) wheat-barley substitution line by crossing with the line CO4-1, which carries the $P h$ suppressor gene from Aegilops speltoides. Kruppa et al. (2013) reported the development of a 4HL.5DL Robertsonian translocation line after crossing the 4H(4D) wheatbarley substitution line with the CSphlb mutant. The rearrangement was confirmed with sequential GISH, FISH and SSR markers. A spontaneous wheat-barley translocation was identified using sequential GISH, FISH and SSR markers by Cseh et al. (2011) in the progenies of the Asakaze $\times$ Manas hybrid. This translocation line carries a 4BS wheat chromosome arm and a 7HL chromosome arm from the Ukrainian six-rowed winter barley. Another spontaneous wheat/ barley translocation line was identified as 5HS7DS.7DL in the progenies of the Mv9kr1 $\times$ Igri wheat-barley hybrid (Kruppa et al. 2013). Despite the non-compensating nature of the translocation, the plants showed good viability. Of the 45 microsatellite markers analysed, ten failed to amplify any 7DSspecific fragments, signalling the elimination of a short chromosome segment in the telomeric region. The breakpoint of the 5HS-7DS.7DL translocation appeared to be more distal than that of reported deletion lines, thus providing a new physical landmark for future deletion mapping studies.

\section{Characterization and exploitation of wheat-barley introgression lines}

Alien additions are primarily produced to add specific desirable genes to a crop species (Gale and Miller
1987), but addition lines can be used for many other purposes, such as mapping genes and markers on introgressed alien chromosomes, examining alien gene regulation, understanding meiotic pairing behaviour and chromosome structure, and isolating individual chromosomes and genes of interest (Chang and de Jong 2005; Cho et al. 2006). The wheat-barley addition lines produced in various cultivar combinations $(\mathrm{CS} \times$ Betzes, Mv9 kr1 $\times$ Igri, Asakaze $\times$ Manas) had several morphological traits in common (Molnár-Láng et al. 2012). The 4H additions had the best fertility and $7 \mathrm{H}$ the lowest in all three combinations. The $2 \mathrm{H}$ addition line had a lax spike structure in every cultivar combination. The $3 \mathrm{H}$ addition had the shortest, most compact spike of all the addition lines in the Mv9kr1-Igri and CS-Betzes sets. The $3 \mathrm{H}$ Asakaze-Manas addition also had a short spike, but it was not as dense as in the other two combinations. This addition line showed a high level of genetic instability, which cannot yet be explained. The $4 \mathrm{H}$ addition line had the tallest plants and $3 \mathrm{H}$ the shortest. The $6 \mathrm{H}$ and $7 \mathrm{H}$ additions were shorter than the $4 \mathrm{H}$, as also observed in the Mv9kr1-Igri addition lines. Unfortunately the $5 \mathrm{H}$ addition could not be selected from the Mv9 $\mathrm{kr} 1 \times$ Igri and Asakaze $\times$ Manas combinations, as this chromosome was eliminated most frequently from the backcross progenies (Molnár-Láng et al. 2005). Barley chromosome $1 \mathrm{H}$ caused sterility even in the presence of other barley chromosomes such as $2 \mathrm{H}, 3 \mathrm{HS}, 4 \mathrm{H}, 5 \mathrm{HS}$ and $7 \mathrm{H}$. A fertile addition line involving the entire barley chromosome $1 \mathrm{H}$ could not be produced by Islam et al. (1978) because a gene on the long arm of this chromosome caused sterility when present in a wheat background. The double monosomic $1 \mathrm{H}$ and $6 \mathrm{H}$ addition became partly female fertile and a few backcross seeds were produced after pollinating them with normal wheat (Islam and Shepherd 1990). Plants disomic for $6 \mathrm{H}$ and monosomic for $1 \mathrm{H}$ were developed, which had some self-fertility (Islam and Shepherd 2000). Unfortunately none of the $\mathrm{BC}_{2}$ plants from the Asakaze $\times$ Manas and Mv9 kr1 $\times$ Igri combinations carried the barley chromosomes $6 \mathrm{H}$ and $1 \mathrm{H}$ together.

Hart et al. (1980) used differences between wheat and barley isozymes to determine the chromosomal locations of barley structural genes for these isozymes. Genes controlling more than 58 isozymes have been allocated to specific barley chromosomes or to arms 

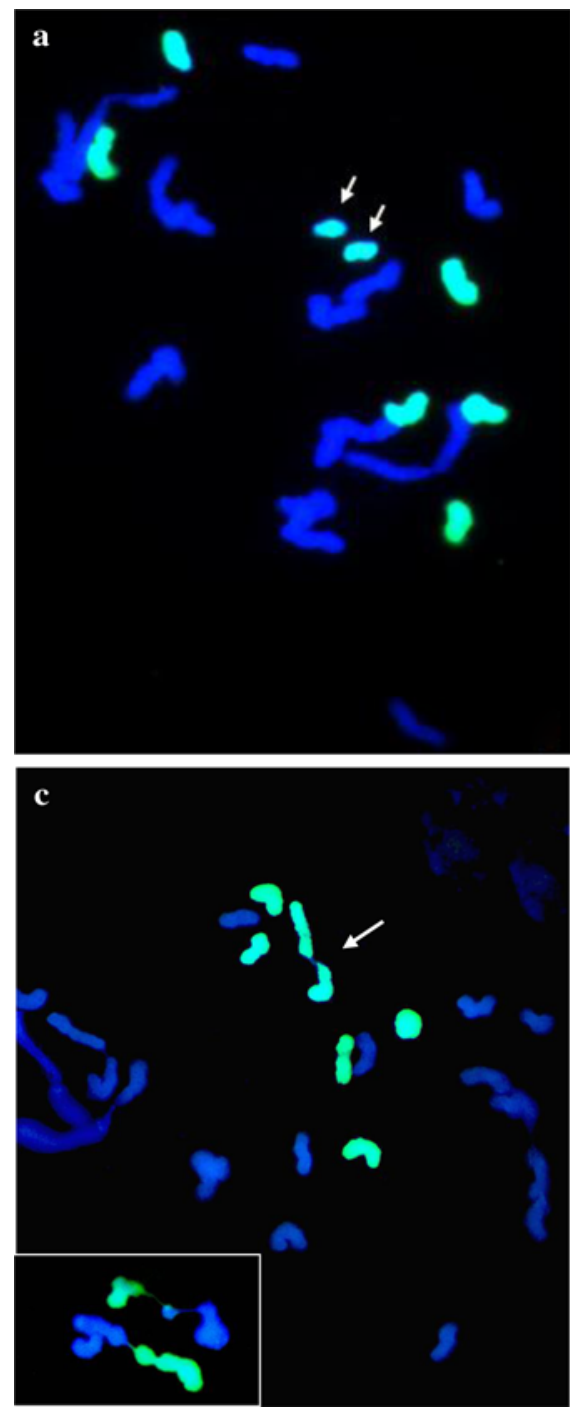

Fig. 1 GISH on meiotic chromosomes (a-d) of wheat-barley (Asakaze-Manas) hybrids multiplied in vitro. Total barley genomic DNA was labelled with Fluorogreen and used as a probe. Wheat chromosomes counterstained with DAPI. a Six barley univalents and two misdivided barley chromosomes (arrows). b A wheat ring bivalent pairing with a barley

thereof using the wheat-barley addition lines (Islam and Shepherd 1990). The effect of the added barley chromosomes on heading characters was studied by Murai et al. (1997) using the CS-Betzes addition lines produced by Islam et al. (1978) together with the $5 \mathrm{H}$ and $6 \mathrm{H}$ Shinchunaga/New Golden additions produced by Koba et al. (1997). The earliest flowering was observed on the CS-Betzes 5H addition line and on the Shinchunaga/New Golden $5 \mathrm{H}$ addition lines. Murai
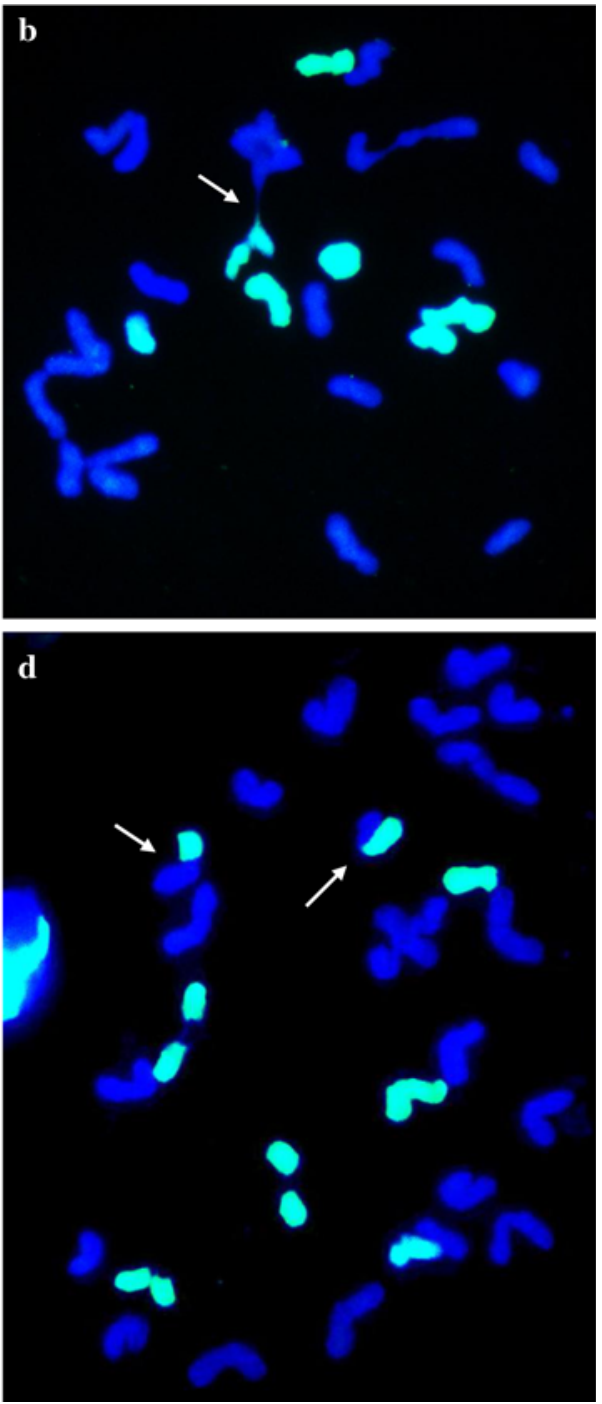

chromosome making a trivalent configuration (arrow). c Five barley univalents and a barley-barley chromosome pairing (arrows). Two wheat-barley bivalents (part of another cell, small box). d Two wheat-barley translocations (arrows), four barley univalents and two misdivided chromosomes

et al. (1997) demonstrated that the heading characters of wheat can be altered by barley genes. The Mv9kr1Igri and Asakaze-Manas wheat/winter barley addition lines made it possible to study the effects of chromosomes from winter barley cultivars on flowering time in the wheat genetic background under various environmental conditions (Farkas et al. 2013). The winter barley chromosome additions significantly influenced the flowering time of wheat both in a 
controlled environment test and under field-sown conditions. Unfortunately the $5 \mathrm{H}$ addition was missing from both combinations, because $5 \mathrm{H}$ was the first chromosome to be eliminated from the backcross derivatives (Molnár-Láng et al. 2005, 2012; Szakács and Molnár-Láng 2010). Of all the barley addition lines, the effect of the $4 \mathrm{H}$ and $7 \mathrm{H}$ additions was the most characteristic. The $7 \mathrm{H}$ addition lines were the earliest in both cultivar combinations in each treatment. In the Mv9kr1-Igri combination the $4 \mathrm{H}$ addition was the latest under all the environmental conditions. In the Asakaze-Manas combination the $4 \mathrm{H}$ addition was the latest under short-day and long-day illumination in the phytotron, but the $6 \mathrm{H}$ addition was the latest without vernalisation and in the field in 2012. There was 12 and 11 days' difference between the flowering times of the $7 \mathrm{H}$ and $4 \mathrm{H}$ Mv9kr1-Igri and AsakazeManas addition lines in the field in 2012, which increased to 52 and 44 days under short-day illumination in the phytotron (Farkas et al. 2013). Only two days' difference was observed between the CS-Betzes $7 \mathrm{H}$ and $4 \mathrm{H}$ addition lines by Murai et al. (1997) under short-day illumination in the phytotron, which could be primarily due to the fact that Betzes, being a spring barley, did not carry the ZCCT-H genes at the VRN$\mathrm{H} 2$ locus, giving further indirect proof that the effect of Vrn-H2 was detected in these addition lines.

The dietary fibre $(1,3 ; 1,4)$ - $\beta$-D-glucan ( $\beta$-glucan), is a major quality parameter of cereals. Barley $\beta$-glucans are beneficial to human health, as they are a major source of soluble dietary fibre and have been recognized both as potential cholesterol-lowering polysaccharides (Kerckhoffs et al. 2003) and as non-specific immune-activators (Allendorf et al. 2005). The grain of barley is one of the most important $\beta$-glucan sources having a $\beta$-glucan content ten times higher than that of wheat. The cellulose synthase-like F6 (CslF6) gene, encoding a putative $\beta$-glucan synthase, has been assigned to the $7 \mathrm{H}$ chromosome (Burton et al. 2008). The presence of the HvCslF6 gene, responsible for $(1,3 ; 1,4)$ - $\beta$-D-glucan production, was revealed in the centromeric region of $7 \mathrm{HL}$ using the 4BS.7HL Asakaze-Manas translocation line (Cseh et al. 2011). An increased $(1,3 ; 1,4)-\beta$-D-glucan level was also detected in the translocation line, demonstrating that the HvCslF6 gene is of potential relevance for the manipulation of wheat $(1,3 ; 1,4)$ - $\beta$-D-glucan levels. The Mv9kr1-Igri 1HS ditelosomic and Mv9kr1-Igri $7 \mathrm{H}$ disomic wheat/barley addition lines carrying the
HvCslF9 and HvCslF6 barley genes, respectively, were used to investigate the additive effect of barley cellulose synthase-like genes on the wheat $\beta$-glucan content (Cseh et al. 2013). A significantly higher $\beta$ glucan level was detected in the leaves and grains of the wheat/barley $1 \mathrm{HS}$ and $7 \mathrm{H}$ addition lines compared to the control wheat line. The expression of the HvCslF9 and HvCslF6 genes in the genetic background of wheat was also determined by quantitative RT-PCR, and the HvCslF9 gene was mapped to the short arm of the $1 \mathrm{H}$ chromosome (Cseh et al. 2013). The HvGlbl barley gene, encoding $(1,3 ; 1,4)-\beta$-Dglucan endohydrolase isoenzyme EI, is possibly involved in the regulation of the $\beta$-glucan level during grain development. Previously this was also mapped to the barley $1 \mathrm{H}$ chromosome, and this study made it clear that it was located on the 1HL chromosome arm. Zou et al. (2012) recently identified wheat-barley 2HL chromosome translocation lines derived from crosses between CS-Betzes $2 \mathrm{H}$ disomic substitution lines and Chinese wheat varieties. These translocations carry the Isa gene encoding the barley bifunctional $\alpha$ amylase/subtilisin inhibitor (BASI). Because BASI is more effective in inhibiting wheat AMY2 than the $\alpha$ amylase inhibitors of other cereals (Henry et al. 1992), the introduction of the barley Isa gene into wheat may regulate endogenous $\alpha$-amylase activity during starch granule synthesis in the developing grain and reduce the level of preharvest sprouting damage.

Wheat-barley chromosome addition lines are useful genetic resources for studying the transcript accumulation patterns of barley in a wheat genetic background and for the large-scale physical mapping of genes. In a study performed by Cho et al. (2006) the CS-Betzes addition lines were examined with the Barley1 Affymetrix GeneChip probe array and a total of 1,787 barley transcripts were detected and physically mapped to barley chromosomes and to the long and short arms of chromosome $6 \mathrm{H}$. The same method and plant materials were used to physically map barley genes to their respective chromosome arm locations by Bilgic et al. (2007), who mapped 1,257 barley genes to chromosome arms $1 \mathrm{HS}, 2 \mathrm{HS}, 2 \mathrm{HL}, 3 \mathrm{HS}$, $3 \mathrm{HL}, 4 \mathrm{HS}, 4 \mathrm{HL}, 5 \mathrm{HS}, 5 \mathrm{HL}, 7 \mathrm{HS}$ and $7 \mathrm{HL}$. The number of genes assigned to individual chromosome arms ranged from 24 to 197 .

Flow sorting can be effective for isolating large samples of alien chromosomes from metaphase suspensions if the flow karyograms of sorted additions 
demonstrate distinct peaks not present in those of the parental species (Suchánková et al. 2006). The telocentric chromosomes of Betzes barley were isolated from the CS-Betzes ditelosomic addition lines, thus allowing the barley genome to be dissected into fractions each representing only about $6-12 \%$ of the total genome (Suchánková et al. 2006). The DNA of flow-sorted chromosomes can be used for the isolation of molecular markers, for physical mapping using PCR and FISH, for the integration of genetic and physical maps and for the construction of chromosome-specific DNA libraries, including sequences cloned in bacterial artificial chromosome vectors. The first barley chromosome to be isolated by flow sorting and shotgun sequencing was $1 \mathrm{H}$ (Mayer et al. 2009). As there is no significant difference in the size of the barley chromosomes, the other six chromosomes could only be sorted from wheat/barley ditelosomic addition lines, in spite of that some barley chromosomes are identifiable based on morphology.

Twelve barley chromosome arms (2HS to 7HL) were purified separately by flow cytometry (Suchánková et al. 2006), after which the DNA was amplified by multiple displacement amplification (MDA) and then shotgun sequenced (Mayer et al. 2011). Using this procedure, between 2,261 and 3,616 genes were tentatively positioned along each of the individual barley chromosomes, representing a cumulative set of 21,766 genes across the entire barley genome. An additional set of 5,815 genes could not be integrated into the genome zippers based on conserved synteny models, but were associated with individual chromosomes/chromosome arms. Overall, it was possible to tentatively position 27,581 barley genes, or $86 \%$ of the estimated 32,000 gene repertoire of the barley genome, into chromosomal regions (Mayer et al. 2011). Among the 21,766 genes anchored to the genome zipper, 3,125 (14\%) genes were allocated to the genetic centromeres. Based on the 454 sequenceand array-based gene assignments to chromosome arms, all but nine of these 3,125 genes were distributed to specific arms of chromosomes $1 \mathrm{H}$ to $7 \mathrm{H}$.

From the practical point of view new wheat-barley hybrids need to be produced using a wider range of barley genotypes carrying genes responsible for useful agronomic traits (e.g. drought tolerance, high $\beta$-glucan content, salt tolerance, earliness). The major limitation for successful gene transfer from barley into wheat is the low crossability between these species. The efficiency with which wheat $x$ barley hybrids can be produced should be increased by hormone treatment at pollination, and by improving the yield of embryo culture. Among the various methods available for producing translocations from wheat $\times$ barley hybrids and additions, the gametocidal system is currently the most promising. Although Tritordeum already exists as the product of the wheat $\times H$. chilense combination, and fertile amphiploids have been produced with $H$. marinum and $H$. californicum, fertile $T$. aestivum $\times H$. vulgare amphiploids have not yet been developed. Unfortunately the chromosome $1 \mathrm{H}$ of $H$. vulgare carries a gene $(S h w)$ that causes sterility in wheat background (Taketa et al. 2002) and it prevents the production of a fertile amphiploid. The development of small barley introgressions in the wheat genetic background has been started, but a much larger quantity of translocations carrying genes responsible for useful traits are needed. Wheat/barley translocations are ideal material for the physical mapping of wheat and barley chromosomes, as the two genomes can be clearly identified using GISH, and the physical landmarks can be used in genome mapping.

Acknowledgments This work was supported by the Hungarian National Scientific Research Fund (OTKA K 104382), by TÁMOP projects (4.2.2.-B-10/1-2010-0025 and 4.2.2.A-11/1/KONV-2012-0064) and by a "Bolyai János" Research Fellowship to G. Linc. Thanks are due to B. Hooper for revising the manuscript linguistically.

Open Access This article is distributed under the terms of the Creative Commons Attribution License which permits any use, distribution, and reproduction in any medium, provided the original author(s) and the source are credited.

\section{References}

Allendorf DJ, Yan J, Ross GD, Hansen RD, Baran JT, Subbarao K, Wang L, Haribabu B (2005) C5a-mediated leukotriene B4-amplified neutrophil chemotaxis is essential in tumor immunotherapy facilitated by anti-tumor monoclonal antibody and beta-glucan. J Immunol 174:7050-7056

Ashida T, Nasuda S, Sato K, Endo TR (2007) Dissection of barley chromosome $5 \mathrm{H}$ in common wheat. Genes Genet Syst 82:123-133. doi:10.1266/ggs.82.123

Armstrong KC, Nakamura C, Keller WA (1983) Karyotype instability in tissue culture regenerants of Triticale ( $\times$ Triticosecale Wittmack) cv. 'Welsh' from 6-month-old callus cultures. Z Pflanzenzüchtg 91:233-245 
Bai D, Knott DR (1993) The effects of level of 2,4-D and time in culture on regeneration rate and chromosome numbers of regenerants from calli of the hybrid Triticum aestivum $\mathrm{cv}$. Chinese Spring phlb $\times$ Thinopyrum ponticum $(2 \mathrm{n}=10 \mathrm{x}$ = 70). Genome 36:166-172. doi:10.1139/g93-022

Barcelo P, Hagel C, Becker D, Martín A, Lörz H (1994) Transgenic cereal (tritordeum) plants obtained at high efficiency by microprojectile bombardment of inflorescence tissue. Plant J 5:583-592. doi:10.1007/s11627-9970003-0

Barclay IR (1975) High frequencies of haploid production in wheat (Triticum aestivum) by chromosome elimination. Nature (London) 256:410-411. doi:10.1038/256410a0

Bilgic H, Cho S, Garvin DF, Muehlbauer GJ (2007) Mapping barley genes to chromosome arms by transcript profiling of wheat-barley ditelosomic chromosome addition lines. Genome 50:898-906. doi:10.1139/G07-059

Blanco A, Fracchiolla GV, Greco B (1986) Intergeneric wheat $\times$ barley hybrid. J Hered 77:98-100

Bothmer R, von Flink J, Landström T (1986) Meiosis in interspecific Hordeum hybrids. I. Diploid combinations. Can J Genet Cytol 28:525-535. doi:10.1139/g86-077

Bothmer R, von Flink J, Landström T (1987) Meiosis in interspecific Hordeum hybrids II. Triploid hybrids. Evol Trends Plants 1:41-50

Burton RA, Jobling SA, Harvey AJ, Shirley NJ, Mather DE, Bacic A, Fincher GB (2008) The genetics and transcriptional profiles of the cellulose synthase-like $H v C s l F$ gene family in barley. Plant Physiol 146:1821-1833. doi:10. 1104/pp.107.114694

Cabrera A, Friebe B, Jiang J, Gill BS (1995) Characterization of Hordeum chilense chromosomes by C-banding and in situ hybridization using highly repeated DNA probes. Genome 38:435-442. doi:10.1139/g95-057

Chang SB, de Jong H (2005) Production of alien chromosome additions and their utility in plant genetics. Cytogenet Genome Res 109:335-343. doi:10.1159/000082417

Chapman V, Miller TE (1978) The amphiploid of Hordeum chilense $\times$ Triticum aestivum. Cereal Res Commun 6:351-352

Cho S, Garvin DF, Muehlbauer GJ (2006) Transcriptome analysis and physical mappping of barley genes in wheatbarley addition lines. Genetics 172:1277-1285. doi:10. 1534/genetics.105.049908

Chu CC, Sun CS, Chen X, Du Zhang WX (1984) Somatic embryogenesis and plant regeneration in callus from inflorescences of Hordeum vulgare $\times$ Triticum aestivum hybrids. Theor Appl Genet 68:375-379. doi:10.1007/ BF00267892

Clauss E (1980) Trigeneric hybrids between barley, wheat and rye. Cereal Res Commun 2:341-345

Clauss E (1983) Bastarde aus Hordeum geniculatum All. Und Triticum aestivum L. Arch Züchtungforsch 13:413-418

Cseh A, Kruppa K, Molnár I, Rakszegi M, Doležel J, MolnárLáng M (2011) Characterization of a new 4BS.7HL wheatbarley translocation line using GISH, FISH, and SSR markers and its effect on the $\beta$-glucan content of wheat. Genome 54:795-804. doi:10.1139/g11-044

Cseh A, Soós V, Rakszegi M, Türkösi E, Balázs E, Molnár-Láng M (2013) Expression of HvCslF9 and HvCslF6 barley genes in the genetic background of wheat and their influence on the wheat $\beta$-glucan content. Ann Appl Biol 163:142-150 (ISSN 0003-4746)

Cubero JI, Martín A, Millan T, Gomez-Cabrera A, De Haro A (1986) Tritordeum: a new alloploid of potential importance as a protein source crop. Crop Sci 26:1186-1190

Dahleen LS (1999) Tissue culture increases meiotic pairing of regenerants from barley $\times$ Canada wild rye hybrids. J Hered 90:265-269. doi:10.1093/jhered/90.2.265

Dewey DR (1984) The genomic system of classification as a guide to intergeneric hybridization with the perennial Triticeae. In: Gustafson JP (ed) Gene manipulation in plant improvement. Plenum Publishing Corporation, New York, pp 209-279

Doré C, Cauderon Y, Chueca MC (1988) Inflorescence culture of Triticum aestivum $\times$ Secale cereale hybrids: production, characterization and cytogenetic analysis of regenerated plants. Genome 30:511-518. doi:10.1139/g88-086

Endo TR (2009) Cytological dissection of barley genome by the gametocidal system. Breed Sci 59:481-486. doi:10.1270/ jsbbs.59.481

Farkas A, Molnár I, Kiss T, Karsai I, Molnár-Láng M (2013) Effect of added barley chromosomes on the flowering time of new wheat/winter barley addition lines in various environments. Euphytica. doi:10.1007/s10681-013-0970-7

Fedak G (1977) Increased homoeolous chromosome pairing in Hordeum vulgare $\times$ Triticum aestivum hybrids. Nature 266:529-530. doi:10.1038/266529a0

Fedak G (1980) Production, morphology and meiosis of reciprocal barley-wheat hybrids. Can J Genet Cytol 22:117-123. doi:10.1139/g80-014

Fedak G (1983) Hybrids between Hordeum pubiflorum and Triticum aestivum. Barley Genet Newslett 13:59

Fedak G (1985) Propagation of intergeneric hybrids of Triticeae through callus culture of immature inflorescence. Z Pflanzenzüchtg 94:1-7

Fedak G, Jui PY (1982) Chromosomes of Chinese Spring wheat carrying genes for crossability with Betzes barley. Can J Genet Cytol 24:227-233

Fedak G, Grainger J (1986) Chromosome instability in somaclones of a Triticum crassum $\times$ Hordeum vulgare hybrid. Can J Genet Cytol 28:618-623. doi:10.1139/g86-090

Fedak G, Armstrong KC, Handyside RJ (1987) Chromosome instability in wheat plants regenerated from suspension culture. Genome 29:627-629. doi:10.1139/g87-104

Fernandez JA, Gonzalez JM, Jouve N (1985) Meiotic pairing of the amphiploid Hordeum chilense $\times$ Triticum turgidum conv. durum studied by means of Giemsa C-banding technique. Theor Appl Genet 70:85-91. doi:10.1007/ BF00264487

Fernandez-Escobar J, Martín A (1985) Morphology, cytology and fertility of a trigeneric hybrid from Triticale $\times$ Tritordeum. Z Pflanzenzüchtg 95:311-318

Finch RA, Bennett MD (1980) Meiotic and mitotic chromosome behaviour in new hybrids of Hordeum with Triticum and Secale. Heredity 44:201-209. doi:10.1038/hdy.1980.17

Gale MD, Miller TE (1987) The introduction of alien genetic variation into wheat. In: Lupton FGH (ed) Wheat breeding: its scientific basis. Chapman and Hall, London, pp 173-210

Galiba G, Molnár-Láng M, Sutka J (1986) In vitro multiplication of a barley (Hordeum vulgare L.) $\times$ wheat (Triticum aestivum L.) hybrid. Növénytermelés 35:481-485 
Griffiths S, Sharp R, Foote TN, Bertin I, Wanous M, Reader S, Colas I, Moore G (2006) Molecular characterization of Phl as a major chromosome pairing locus in polyploid wheat. Nature 439:749-752. doi:10.1038/nature04434

Gupta PK, Fedak G (1985) Intergeneric hybrids between Hordeum californicum and Triticum aestivum. J Hered 76:365-368

Hart GE, Islam AKMR, Shepherd KW (1980) Use of isozymes as chromosome markers in the isolation and characterization of wheat-barley chromosome addition lines. Genet Res Camb 36:311-325

Henry RJ, Battershell VG, Brennan PS, Onon K (1992) Control of wheat $\alpha$-amylase using inhibitors from cereals. J Sci Food Agric 58:281-284. doi:10.1002/jsfa.2740580218

Hernandez P, Barcelo P, Lazzeri PA, Lörz H, Martín A, Bohanec B (2001) Agronomic performance of transgenic Tritordeum. Biotechnological approaches for utilisation of gametic cells. COST 824 Final Meeting, Bled, Slovenia, 1-5 July 2000, pp 199-204

Islam AKMR, Colmer TD (2008) Attempts to transfer salt- and waterlogging tolerances from sea barleygrass (Hordeum marinum Huds.) to wheat. In: Appels R, Eastwood R, Lagudah E, Langridge P, Mackay M, McIntyre L, Sharp P (eds) Proceedings of the 11th International Wheat Genetics Symposium, Brisbane, Australia. Sydney University Press, Sydney, pp 336-338

Islam AKMR, Shepherd KW (1980) Meiotic restitution in wheat-barley hybrids. Chromosoma 79:363-372. doi:10. 1007/BF00327326

Islam AKMR, Shepherd KW (1988) Induced pairing between wheat and barley chromosomes. In: Miller TE, Koebner RMD (eds) Proceedings of the 7th International Wheat Genetics Symposium, Cambridge, England, pp 309-314

Islam AKMR, Shepherd KW (1990) Incorporation of barley chromosomes into wheat. In: Bajaj YPS (ed) Biotechnology in agriculture and forestry wheat, vol 13. Springer, Heidelberg, pp 128-151

Islam AKMR, Shepherd KW (1992a) Production of wheatbarley recombinant chromosomes through induced homoeologous pairing. 1. Isolation of recombinants involving barley arms 3HL and 6HL. Theor Appl Genet 83:489-494. doi:10.1007/BF00226538

Islam AKMR, Shepherd KW (1992b) Substituting ability of individual barley chromosomes for wheat chromosomes. 1 . Substitutions involving barley chromosomes 1,3 and 6 . Plant Breed 109:141-150. doi:10.1111/j.1439-0523.1992. tb00164.x

Islam AKMR, Shepherd KW (1995) Substitution of barley chromosome 4 for group 4 homoelogous of wheat. In: $\mathrm{Li}$ ZS, Xin ZY (eds) Proceedings of the 8th International Wheat Genetics Symposium, Beijing, China, 20-25 July 1993. China Agricultural Scientech Press, Beijing, pp 141-144

Islam AKMR, Shepherd KW (2000) Isolation of a fertile wheatbarley addition line carrying the entire barley chromosome 1H.Euphytica 111:145-149. doi:10.1023/A:1003822719317

Islam AKMR, Shepherd KW, Sparrow DHB (1975) Addition of individual barley chromosomes to wheat. In: Gaul H (ed) Proceedings of the 3rd International Barley Genetics Symposium, Verlag Karl Thiemig, Munich, Germany, pp 260-270
Islam AKMR, Shepherd KW, Sparrow DHB (1978) Production and characterization of wheat-barley addition lines. In: Ramanujam S (ed) Proceedings of the 5th International Wheat Genetics Symposium. Science Publishers Inc., India, pp 356-371

Islam AKMR, Shepherd KW, Sparrow DHB (1981) Isolation and characterization of euplasmic wheat-barley chromosome addition lines. Heredity 46:160-174. doi:10.1038/ hdy.1981.24

Islam S, Malik AI, Islam AKMR, Colmer TD (2007) Salt tolerance in a Hordeum marinum-Triticum aestivum amphiploid and its parents. J Exp Bot 58:1219-1229. doi:10. 1093/jxb/erl293

Jauhar PP (1995) Morphological and cytological characteristics of some wheat $\times$ barley hybrids. Theor Appl Genet 90:872-877. doi:10.1007/BF00222025

Jiang J, Dajun L (1987) New Hordeum-Triticum hybrids. Cereal Res Commun 15:95-99

Junming L, Mei Z, Tishu C (1985) Somaclonal variation in intergeneric hybrids of Hordeum vulgare $\times$ Triticum aestivum. Acta Genet Sin 12:434-439

Kerckhoffs DA, Hornstra G, Mensink RP (2003) Cholesterollowering effect of beta-glucan from oat bran in mildly hypercholesterolemic subjects may decrease when betaglucan is incorporated into bread and cookies. Am J Clin Nutr 78:221-227

Kimber G, Sallee PJ (1976) A hybrid between Triticum timopheevii and Hordeum bogdanii. Cereal Res Commun 4:33-37

Koba T, Handa T, Shimada T (1991) Efficient production of wheat-barley hybrids and preferential elimination of barley chromosomes. Theor Appl Genet 81:285-292. doi:10. 1007/BF00228665

Koba T, Shimada T, Otani M, Niizeki H (1988) Chromosomal and morphological variation in plants regenerated from calli of immature embryos and inflorescences of a barleywheat hybrid. In: Miller TE, Koebner RMD (eds) Proceedings of the 7th International Wheat Genetics Symposium, Cambridge, England, pp 757-762

Koba T, Takumi S, Shimada T (1997) Isolation, identification and characterization of disomic and translocated barley chromosome addition lines of common wheat. Euphytica 96:289-296. doi:10.1023/A:1003081619338

Kruppa K, Sepsi A, Szakács É, Röder MS, Molnár-Láng M (2013) Characterization of a 5HS-7DS.7DL wheat-barley translocation line and physical mapping of the 7D chromosome using SSR markers. J Appl Genet 54:251-258. doi:10.1007/s13353-013-0152-2

Kruse A (1973) Hordeum $\times$ Triticum hybrids. Hereditas 73:157-161. doi:10.1111/j.1601-5223.1973.tb01078.x

Larkin PJ, Scowcroft WR (1981) Somaclonal variation-a novel source of variability from cell cultures for plant improvement. Theor Appl Genet 60:197-204. doi:10.1007/ BF02342540

Lima-Brito J, Guedes Pinto H, Harrison GE, Heslop-Harrison JS (1996) Chromosome identification and nuclear architecture in triticale $\times$ tritordeum $\mathrm{F}_{1}$ hybrids. $\mathrm{J}$ Exp Bot 47:583-588. doi:10.1093/jxb/47.4.583

Linde-Laursen I, Heslop-Harrison JS, Shepherd KW, Taketa S (1997) The barley genome and its relationship with the wheat genomes. A survey with internationally agreed 
recommendation for barley chromosome nomenclature. Hereditas 126:1-16. doi:10.1111/j.1601-5223.1997. 00001.x

Löve A (1982) Generic evolution of the wheatgrasses. Biol Zentralbl 101:199-212

Löve A (1984) Conspectus of the Triticeae. Feddes Repert 95:425-521

Malysheva L, Sjakste T, Matzk F, Röder M, Ganal M (2003) Molecular cytogenetic analysis of wheat-barley hybrids using genomic in situ hybridization and barley microsatellite markers. Genome 46:314-322. doi:10.1139/g02-117

Martín A, Chapman V (1977) A hybrid between Hordeum chilense and Triticum aestivum. Cereal Res Commun 5-4:365-366

Martín A, Cubero JI (1981) The use of Hordeum chilense in cereal breeding. Cereal Res Commun 9:317-323

Martín A, Rubiales D, Rubio JM, Cabrera A (1995) Hybrids between Hordeum vulgare and tetra- hexa-, and octoploid tritordeums (amphiploid H. chilense $\times$ Triticum ssp.). Hereditas 123:175-182. doi:10.1111/j.1601-5223.1995. 00175.x

Martín A, Sanchez-Monge Laguna E (1980) A hybrid between Hordeum chilense and Triticum turgidum. Cereal Res Commun 8:349-353

Martín A, Sanchez-Monge Laguna E (1982) Cytology and morphology of the amphiploid Hordeum chilense $\times$ Triticum turgidum conv. durum. Euphytica 31:261-267. doi:10.1007/BF00028329

Martín AC, Atienza SG, Ramirez MC, Barro F, Martín A (2009) Chromosome engineering in wheat to restore male fertility in the msH1 CMS system. Mol Breed 24:397-408. doi:10. 1007/s11032-009-9301-z

Mayer KF, Martis M, Hedley PE, Simková H, Liu H, Morris JA, Steuernagel B, Taudien S, Roessner S, Gundlach H, Kubaláková M, Suchánková P, Murat F, Felder M, Nussbaumer T, Graner A, Salse J, Endo T, Sakai H, Tanaka T, Itoh T, Sato K, Platzer M, Matsumoto T, Scholz U, Dolezel J, Waugh R, Stein N (2011) Unlocking the barley genome by chromosomal and comparative genomics. Plant Cell 23:1249-1263. doi:10.1105/tpc.110.082537

Mayer KFX, Taudien S, Martis M, Simková H, Suchánková P, Gundlach H, Wicker T, Petzold A, Felder M, Steuernagel B, Scholz U, Graner A, Platzer M, Dolezel J, Stein N (2009) Gene content and virtual gene order of barley chromosome 1H. Plant Physiol 151:496-505. doi:10.1104/ pp.109.142612

Miller TE, Reader SM, Chapman V (1981) The addition of Hordeum chilense chromosomes to wheat. Induced variability in plant breeding. In: International Symposium Eucarpia. Pudoc, Wageningen, pp 79-81

Molnár-Láng M, Sutka J (1994) The effect of temperature on seed set and embryo development in reciprocal crosses of wheat and barley. Euphytica 78:53-58. doi:10.1007/ BF00021397

Molnár-Láng M, Galiba G, Kovács G, Sutka J (1991) Changes in the fertility and meiotic behaviour of barley (Hordeum vulgare $) \times$ wheat (Triticum aestivum) hybrids regenerated from tissue cultures. Genome 34:261-266. doi:10.1139/ g91-041

Molnár-Láng M, Kruppa K, Cseh A, Bucsi J, Linc G (2012) Identification and phenotypic description of new wheat- six-rowed winter barley disomic additions. Genome 55:302-311. doi:10.1139/g2012-013

Molnár-Láng M, Linc G, Friebe BR, Sutka J (2000a) Detection of wheat-barley translocations by genomic in situ hybridization in derivatives of hybrids multiplied in vitro. Euphytica 112:117-123. doi:10.1023/A:1003840200744

Molnár-Láng M, Linc G, Logojan A, Sutka J (2000b) Production and meiotic pairing behaviour of new hybrids of winter wheat (Triticum aestivum) $\times$ winter barley (Hordeum vulgare). Genome 43:1045-1054. doi:10.1139/g00-079

Molnár-Láng M, Novotny C, Linc G, Nagy ED (2005) Changes in the meiotic pairing behaviour of a winter wheat-winter barley hybrid maintained for a long term in tissue culture, and tracing the barley chromatin in the progenies using GISH and SSR markers. Plant Breed 124:247-252. doi:10. 1111/j.1439-0523.2005.01097.x

Molnár-Láng M, Sutka J, Barnabás B, Sági L, Belea A (1985) Production of barley (Hordeum vulgare L.) $\times$ wheat (Triticum aestivum L.) hybrids. Növénytermelés 34:257-262

Mujeeb-Kazi A (1981) Apomictic progeny derived from intergeneric Hordeum-Triticum hybrids. J Hered 72:284-285

Mujeeb-Kazi A, Rodriguez R (1983) Meiotic instability in Hordeum vulgare $\times$ Triticum aestivum hybrids. J Hered 74:292-296

Murai K, Koba T, Shimada T (1997) Effects of barley chromosome on heading characters in wheat-barley chromosome addition lines. Euphytica 96:281-287. doi:10.1023/ A: 1003025501591

Nagy ED, Molnár-Láng M, Linc G, Láng L (2002) Identification of wheat-barley translocations by sequential GISH and two-colour FISH in combination with the use of genetically mapped barley SSR markers. Genome 45:1238-1247. doi:10.1139/g02-068

Nakamura C, Keller WA, Fedak G (1981) In vitro propagation and chromosome doubling of a Triticum crassum $\times$ Hordeum vulgare intergeneric hybrid. Theor Appl Genet 60:89-96. doi:10.1007/BF00282423

Nasuda S, Kikkawa Y, Ashida T, Islam AKMR, Sato K, Endo TR (2005) Chromosomal assignment and deletion mapping of barley EST markers. Genes Genet Syst 80:357-366. doi:10.1266/ggs.80.357

Park CH, Kumar PS, Walton PD (1990) Plant regeneration and chromosomal stability in tissue cultures of the hybrids of Elymus canadensis with Psathyrostachys juncea and Secale cereale. Plant Breed 104:184-189. doi:10.1111/j. 1439-0523.1990.tb00421.x

Pershina LA, Shumny VK (1981) A characterization of clonal propagation of barley $\times$ rye and barley $\times$ wheat hybrids by means of tissue cultures. Cereal Res Commun 9:273-279

Pershina LA, Numerova OM, Belova LI, Devyatkina EP, Shumny VK (1988) Fertility in barley $\times$ wheat hybrids $H$. geniculatum All. $\times$ T. aestivum L., their regenerants and hybrid progeny of backcrosses to T. aestivum L. Cereal Res Commun 16:157-163

Pershina LA, Deviatkina EP, Belova LI, Trubacheeva NV, Arbuzova VS, Kravtsova LA (2009) Features of alloplasmic wheat-barley substitution and addition lines (Hordeum marinum subsp. gussoneanum)-Triticum aestivum. Genetika 45:1386-1392. doi:10.1134/S102279540910010X 
Riley R, Chapman V (1958) Genetic control of cytologically diploid behaviour of hexaploid wheat. Nature 182:713715. doi:10.1038/182713a0

Riley R, Law CN (1965) Genetic variation in chromosome pairing. Adv Genet 13:57-114. doi:10.1016/S00652660(08)60047-4

Sakai K, Nasuda S, Sato K, Endo TR (2009) Dissection of barley chromosome $3 \mathrm{H}$ in common wheat and a comparison of physical and genetic maps. Genes Genet Syst 84:25-34. doi: $10.1266 /$ ggs. 84.25

Schubert I, Shi F, Fuchs J, Endo TR (1998) An efficient screening for terminal deletions and translocations of barley chromosomes added to common wheat. Plant $\mathbf{J}$ 14:489-495. doi:10.1046/j.1365-313X.1998.00125.x

Schwarzacher T, Anamthawat-Jónsson K, Harrison GE, Islam AKMR, Jia JZ, King IP, Leitch AR, Miller TE, Reader SM, Rogers WJ, Shi M, Heslop-Harrison JS (1992) Genomic in situ hybridization to identify alien chromosomes and chromosome segments in wheat. Theor Appl Genet 84:778-786. doi:10.1007/BF00227384

Sears ER (1956) The transfer of leaf rust resistance from Aegilops umbellulata to wheat. Brookhaven Symp Biol 9:1-22

Sears ER (1972) Chromosome engineering in wheat. Stadler Symp 4:23-38

Sears ER (1976) Genetic control of chromosome pairing in wheat. Ann Rev Genet 10:31-51. doi:10.1146/annurev.ge. 10.120176.000335

Sepsi A, Németh K, Molnár I, Szakács É, Molnár-Láng M (2006) Induction of chromosome rearrangements in a 4H(4D) wheat-barley substitution using a wheat line containing a $p h$ suppressor gene. Cereal Res Commun 34:1215-1222. doi:10.1556/CRC.34.2006.4.261

Serizawa N, Nasuda S, Shi F, Endo TR, Prodanovic S, Schubert I, Künzel G (2001) Deletion-based physical mapping of barley chromosome 7H. Theor Appl Genet 103:827-834. doi: $10.1007 / \mathrm{s} 001220100703$

Sethi GS, Finch RA, Miller TE (1986) A bread wheat (Triticum aestivum) $\times$ cultivated barley (Hordeum vulgare) hybrid with homoeologous chromosome pairing. Can J Genet Cytol 28:777-782. doi:10.1139/g86-109

Sharma HC, Gill BS, Sears RG (1984) Inflorescence culture of wheat-Agropyron hybrids: callus induction, plant regeneration, and potential in overcoming sterility barriers. Plant Cell Tissue Organ Cult 3:247-255. doi:10.1007/ BF00040344

Sherman JD, Smith LY, Blake TK, Talbert LE (2001) Identification of barley genome segments introgressed into wheat using PCR markers. Genome 44:38-44. doi:10.1139/g00-092

Shimada T, Koba T, Otani M, Niizeki H (1987) Morphology, meiosis and in vitro propagation of barley-wheat hybrids. In: Proceedings of the 5th International Wheat Genetics Symposium, Okayama, pp 343-350

Shumny VK, Pershina LA (1979) Production of barley-rye hybrids and their clonal propagation by the method of isolated tissue cultivation. Dokl Acad Nauk SSSR 249:218-220

Shumny VK, Pershina LA, Belova LI (1981) Production of barley $\times$ rye and barley $\times$ wheat hybrids. Cereal Res Commun 4:265-272

Suchánková $\mathrm{P}$, Kubaláková $\mathrm{M}$, Kovářová $\mathrm{P}$, Bartoš J, Č́íhalíková J, Molnár-Láng M, Endo TR, Dolezel J (2006) Dissection of the nuclear genome of barley by chromosome flow sorting. Theor Appl Genet 113:651-659. doi:10.1007/ s00122-006-0329-8

Surikov JM, Kissel NI (1988) Mikroklonirovanie yachmennopshenichnikh gibridov. Dokl Vasknil 1:2-4

Svitashev S, Bryngelsson T, Vershinin A, Pedersen C, Säll T, von Bothmer R (1994) Phylogenetic analysis of the genus Hordeum using repetitive DNA sequences. Theor Appl Genet 89:801-810. doi:10.1007/BF00224500

Szakács É, Molnár-Láng M (2007) Development and molecular cytogenetic identification of new winter wheat/winter barley (Martonvásári $9 \mathrm{kr}$ 1/Igri) disomic addition lines. Genome 50:43-50. doi:10.1139/g06-134

Szakács É, Molnár-Láng M (2010) Identification of new winter wheat-winter barley addition lines $(6 \mathrm{HS}$ and $7 \mathrm{H})$ using fluorescence in situ hybridization and stability of the whole 'Martonvásári 9 kr1'-'Igri' addition set. Genome 53:35-44. doi:10.1139/G09-085

Szakács É, Kruppa K, Molnár I, Molnár-Láng M (2010) Induction of wheat/barley translocations by irradiation and their detection by in situ hybridization. Acta Agron Hung 58:203-209. doi:10.1556/AAgr.58.2010.3.2

Taketa S, Kato J, Takeda K (1995) High crossability of wild barley (Hordeum spontaneum $\mathrm{C}$. Koch) with bread wheat and the differential elimination of barley chromosomes in the hybrids. Theor Appl Genet 91:1203-1209. doi:10. 1007/BF00220930

Taketa S, Takahashi H, Takeda K (1998) Genetic variation in barley of crossability with wheat and its quantitative trait loci analysis. Euphytica 103:187-193. doi:10.1023/A: 1018344119747

Taketa S, Takeda K (2001) Production and characterization of a complete set of wheat-wild barley (Hordeum vulgare ssp. spontaneum) chromosome addition lines. Breed Sci 51:199-206. doi:10.1270/jsbbs.51.199

Taketa S, Choda M, Ohashi R, Ichii M, Takeda K (2002) Molecular and physical mapping of a barley gene on chromosome arm 1HL that causes sterility in hybrids with wheat. Genome 45:617-625. doi:10.1139/g02-024

Ter Kuile N, Nabors M, Mujeeb-Kazi A (1988) Callus culture induced amphiploids of Triticum aestivum and T. turgidum $\times$ Aegilops variabilis $\mathrm{F}_{1}$ hybrids: production, cytogenetics and practical significance. In: 80th Annual Meeting American Society of Agronomy, Abstract 98

Thomas JB, Mujeeb-Kazi A, Rodriguez R, Bates LS (1977) Barley $\times$ wheat hybrids. Cereal Res Commun 5:181-188

Ya-Ping Y, Xiao C, Si-He X, Islam AKMR, Zhi-Yong X (2003) Identification of wheat-barley $2 \mathrm{H}$ alien substitution lines. Acta Bot Sin 45:1096-1102

Villegas D, Casadesús J, Atienza SG, Martos V, Maalouf F, Karam F, Aranjuelo I, Nogués S (2010) Tritordeum, wheat and triticale yield components under multi-local mediterranean drought conditions. Field Crop Res 116:68-74. doi:10.1016/j.fcr.2009.11.012

Wojciechowska B (1985) Hybrids between Hordeum vulgare L. and Triticum aestivum L. Genet Pol 26:457-462

Wojciechowska B, Pudelska H (1993) Hybrids from reciprocal barley-wheat crosses. Genet Pol 34:1-13

Zou H, Wu Y, Liu H, Lin Z, Ye X, Chen X, Yuan Y (2012) Development and identification of wheat-barley $2 \mathrm{H}$ chromosome translocation lines carrying the Isa gene. Plant Breed 131:69-74. doi:10.1111/j.1439-0523.2011.01910.x 